\title{
The Role of Public Order Regulations as Acts of Local Law in the Performance of Tasks in the Field of Public Security by Local Self-government in Poland
}

\author{
JAROSŁAW KOSTRUBIEC
}

\begin{abstract}
The subject of the article are the issues concerning the enactment by local self-government bodies in Poland of a special category of acts of local law, i.e. public order regulations. Public order regulations belong to the sources of universally binding law in Poland. Not only government administration bodies, but also local selfgovernment may adopt them. By means of public order regulations, such values as: life, health, property of citizens, environment, public order, peace and public security are protected. The status of public order regulations in the Polish legal order, which are bodies of local selfgovernment units to protect the life or health of citizens and to ensure public order, peace and security, is not the subject to clear legislation or consent among scholars in the field and in relevant case-law. Therefore, the aim of the article is to determine the legal status of local law acts in the form of public order regulations in Poland and to define their role in the performance of tasks in the field of public security by local selfgovernment. The author refers also to relevant legal solutions applicable in other member states of the Visegrad Group. The main thesis of the article is a statement that acts of local law in the form of public order regulations are a desirable manifestation of the law-making decentralisation of the state, which is necessary for the effective performance of tasks in the field of public security by local selfgovernment bodies.
\end{abstract}

Keywords: • local law $\bullet$ public order regulations $\bullet$ public security • local self-government $\bullet$ Poland

Correspondence Address: Jarosław Kostrubiec, Ph.D., Dr. Habil. Associate Professor, Maria Curie-Skłodowska University (Lublin), Faculty of Law and Administration, Plac Marii Curie-Skłodowskiej 5, 20-031 Lublin, Poland, email: j.kostrubiec@umcs.pl.

https://doi.org/10.4335/19.1.111-129(2021)

ISSN 1581-5374 Print/1855-363X Online C) 2021 Lex localis

Available online at http://journal.lex-localis.press. 
J. Kostrubiec: The Role of Public Order Regulations as Acts of Local Law in the Performance of Tasks in the Field of Public Security by Local Self-government in Poland

The article discusses issues related to the legal activities of local government in Poland in the field of adopting public order regulations. The aim of the article is to define the status of public order regulations in the Polish system of sources of law and identify their role in the performance of public security tasks by the local government in Poland. The author intends to demonstrate that the need to ensure the continuity and complementarity of the national security system in Poland justifies the inclusion of local government at municipal and poviat (district, county) levels in its construction and equipping their authorities with the powers to make public order regulations. A novelty of the deliberations contained herein is the approach to the issue in the context of local government's tasks in the field of security and public order and covering the status of acts of local law adopted by local government bodies in the Visegrad Group member states.

The article has been divided into four substantive parts. The first part describes the characteristics of local government tasks in Poland in the field of public security. It was necessary to undertake a scholarly reflection in this regard in view of the aim of the article, namely determination of the importance of public order regulations in ensuring public security. The characteristics of tasks of the local government in the field of public security allowed us to determine the importance in their implementation of law-making powers of local government in Poland consisting in adopting public order regulations. Part two of the article provides the characteristics of public order regulations as sources of law. The system of sources of law in Poland was based on the positive law concept. Public order regulations constitute a special category of local laws which, in addition to the Constitution, statutory laws, ratified international agreements and regulatory acts referred to in Article 87(1) of the Constitution of the Republic of Poland of 2 April 1997 (Journal of Laws No. 78, item 483, as amended) all constitute sources of generally applicable law. The parts three and four provide an analysis of the content, conditions and procedures relating to adopting public order regulations, regarding to two types of local government units in Poland, namely the municipality and the poviat. It should be mentioned here that acts of local law, including public order, regulations, may be adopted not only by local government but also by local bodies of the central government on the basis of and within the limits of the mandates contained in the law (Article 94, Constitution of the Republic of Poland of 2 April 1997).

\section{$2 \quad$ Methodology}

Classical research methods and techniques developed within the framework of legal sciences were used for the research. An important value of legal knowledge is to determine the meaning of statements contained in the legislation. Therefore, 
the basic method used in the research was the formal dogmatic method. In particular, the rules of legal linguistic interpretation were used. This was done in order to analyse and assess the existing legislation governing the enactment of public order regulations and their role in the implementation of tasks of ensuring public security by local government in Poland. The description and systematisation of the legal provisions applicable in this area allowed for the formulation of proposals for the law as it currently stands and for the law as it should stand. In addition, the research used the legal comparative method to approach the issue in view of legal solutions in force in member states of the Visegrad Group. The use of this method made it possible to establish similarities, analogies and differences in enacting public order regulations by local government bodies in the countries covered by the study. As an auxiliary measure, the article uses the theoretical-legal method to determine the position of public order regulations in the system of sources of law in Poland.

\section{$3 \quad$ Literature overview}

The literature on the issues covered by the research scope of this article should be divided into two main groups, relating respectively to the law of public order and security and the law-making activities of local government bodies.

Comprehensive legal-science research in public security in Poland is conducted by M. Karpiuk. It is impossible to list all the scientific publications of this prolific scientist. However, in the context of tasks of local government in the sphere of security, one should first point to the monograph entitled Miejsce samorzadu terytorialnego w przestrzeni bezpieczeństwa narodowego [The Position of Local Government within the Sphere of National Security] (Karpiuk, 2014a). The author examined the mechanisms shaping the national security system in Poland in relation to all local government units, approaching the issue in the political, subjective, organisational, material, process and functional terms. His important contribution to the research on the role of local government in the field of national security was to carry out applied analyses in all the spheres of national security, namely social security, ecological security, public security, cultural security, economic security and military security.

An important contribution to the research on the role of local government in the sphere of security is a collective study published by the Polish National Institute of Local Self-Government, edited by: M. Karpiuk, M. Mazuryk and I. Wieczorek. The monograph comprehensively analyses the tasks and powers of local government in the field of public order and safety of citizens, defence, and fire and flood protection (Karpiuk, Mazuryk \& Wieczorek, 2017). The authors of individual chapters are experts in local government issues who have addressed various aspects related to the performance of tasks by local government in the area 
J. Kostrubiec: The Role of Public Order Regulations as Acts of Local Law in the Performance of Tasks in the Field of Public Security by Local Self-government in Poland

of national security, including social security, environmental security, safety of mass events, fire protection, or during states of emergency.

Referring to the research carried out on local government's law-making activities, it is worth pointing to the study by D. Dąbek Prawo miejscowe [Local Law], which is a comprehensive study on acts of local law. The author has analysed the issue from the point of view of both the theory of law and the rules of adopting and application of local law acts. The value of this book lies especially in the approach to local law from the perspective of practical experience of Polish local law-making, taking into account the case law of administrative courts and decisions of supervisory bodies (Dąbek, 2007: 19).

A collective study edited by B. Dolnicki, entitled Źródła prawa $w$ samorzadzie terytorialnym [Sources of Law in Local Government] (Dolnicki, 2018) occupies an important place in the discussion on the position of acts of local law in the Polish system of sources of law. The content of this monograph consists of articles that analyse issues related to the determination of the meaning of local law acts and other normative acts as a legal basis for the functioning of local government. The value of this publication lies in the fact that the authors also take into consideration those categories of acts that raise theoretical and practical doubts.

The issues of local law have also become the subject of research by K. Sikora, who took his own position in the discussion on local law acts in the field of their judicial and administrative review. The author, apart from many other interesting conclusions, states that a shortcoming of the legal regulations in force in this area is the lack of a uniform and coherent legal regulation on the review of acts of local law (Sikora, 2017: 479).

The issue of acts of local law from the point of view of the legislatve art has become the subject of a monograph entitled Legislacja administracyjna [Legislation in Public Administration], authored by M. Karpiuk, J. Kostrubiec, M. Paździor, K. Popik-Chorąży and K. Sikora (Karpiuk et al., 2013). This study covers, among other things, the issues of local government law-making practices, both from the point of view of theoretical and practical lawmaking, taking into account the review (supervision) of lawmaking activities of public administration.

A monograph, which is a legal comparative and comprehensive study that takes into account the problems of tasks of local government and its law-making powers, is the collective work edited by M. Czuryk, M. Karpiuk and J. Kostrubec entitled Local self-government in the European Union Member-States (Czuryk et al., 2015). Not only does the monograph provide an opportunity to compare the legal solutions in force in individual European Union countries, but it also allows us to learn about the origins of local government and understand its changes and 
development trends. The main message of the book is to show the benefits of decentralisation of public administration and implementing the principle of subsidiarity.

One cannot fully list all the valuable publications about the institution of local government and its legislative activity. Nevertheless, it should be noted that there is no study in Polish literature that would discuss the status of public order regulations as acts of local law in the Polish system of sources of law and their role in the performance of public security tasks by local government in Poland. For this reason, undertaking research in this area should be considered necessary and reasonable.

\section{$4 \quad$ Research and Discussion}

\subsection{Tasks of local government in the field of public security in Poland}

The construction of an appropriate national security system by the state is its essential function. Local government is an important element of this system, which should be understood as an internally coordinated set of forces and resources that the state uses to perform tasks in various areas of security (Karpiuk, 2013: 28). Local government is the form of public authority closest to citizens. Therefore, local government bodies can effectively perform a number of important tasks in the field of public security (Kostrubiec, 2017: 105). The bodies of local community are able to quickly identify and react to threats to the life or health of their residents. This rule was also noticed by the Polish legislature, who assigned a number of tasks to local government units aimed at ensuring order, peace and public security (Karpiuk \& Kostrubiec, 2017: 65). The security needs of the local community are of a basic nature and should be addressed on a continuous basis (Orzeszyna et al., 2020: 78). They are related not only to the proper and undisturbed functioning of public institutions, but also to guaranteeing a proper standard of living for the local community (Karpiuk, 2014a: 29).

The Polish legislature included the matters of public order and security of citizens as well as fire and flood protection among the municipality's own tasks, consisting in meeting the collective needs of the community (Article 7(1) item 14 of the Act of 8 March 1990 on municipal government, Journal of Laws of 2020, item 713, hereinafter: the Act on municipal government). The poviat government performs public tasks of a supra-municipal nature in the following areas: public order and security of citizens; defence; flood protection, fire protection and prevention of other extraordinary threats to human life and health and the environment (Article 4 (1) items 15 to 16 and 20, the Act of 5 June 1998 on poviat government, Journal of Laws of 2020, item 920, hereinafter the Act on poviat government). Similarly, the voivodeship (regional) government in Poland performs specific tasks in the field of defence and public security (Article 14 (1) items 13 to 14 of the Act of 5 
J. Kostrubiec: The Role of Public Order Regulations as Acts of Local Law in the Performance of Tasks in the Field of Public Security by Local Self-government in Poland

June 1998 on voivodeship government, Journal of Laws of 2020, item 1668, hereinafter: the Act on voivodeship government). The above-mentioned tasks in the field of security and public order were defined in competence provisions of a general nature. This means that they cannot constitute an independent legal basis under which local government bodies could issue acts of application of law, in particular administrative decisions, or adopt normative acts. Such powers must be based on special provisions, which clearly indicate the right of a given local government body to take specific actions consisting in the application or enactment of law in order to ensure public security or order (Karpiuk, 2019: 32).

The tasks in the field of public security are performed by local government bodies in Poland in several areas, which have been defined by specific acts. First, local government operates as an element of the rescue system. The authorities of local government units in Poland perform specific tasks as part of the rescue, firefighting and fire protection system. In this respect, the starost (poviat head) has a special status, as he defines the tasks of the national rescue and firefighting system and coordinates and inspects the performance of the resulting tasks. In situations of extraordinary threats to life, health or the environment, the starost manages the rescue and firefighting system (Skoczylas, 2011: 60). On the other hand, the municipal executive bodies perform tasks in the field of coordinating the functioning of the national rescue and firefighting system in their area of responsibility (Article 14 (3) to (5) of the Act of 24 August 1991 on fire protection, Journal of Laws of 2020, item 961). Executive bodies of municipal government in Poland have to some extent been equipped with powers in the field of water rescue system related to ensuring safety in water areas, which they perform as own tasks of the municipality (Article 4 (2) item 3 and paragraph (3) of the Act of 18 August 2011 on the safety of people in water areas, Journal of Laws of 2020, item 350$)$.

The tasks of the local government to ensure public security also include the powers of municipal authorities in the sphere of safety of mass, artistic and entertainment events. The obligation to secure a mass event is mainly borne by the organiser. However, the executive body of the municipality is competent to issue a permit to organise a mass event (Dróżdż, 2014: 175), checks the compliance of the course of a high-risk mass event with the conditions set out in the permit and issues a decision to ban the mass event (Karpiuk, 2020: 85-124; Article 24 and Article 32, Act of 20 March 2009 on the safety of mass events, Journal of Laws of 2019, item 2171).

Local government bodies in Poland have been equipped with extensive powers in the sphere of crisis management and during a state of natural disaster. The crisis management system was built in Poland according to the principle of primacy of the territorial arrangement, which provides for four levels: central, regional 
(voivodeship), poviat and municipal (Czuryk et. al., 2016: 23). Local government is the first stage to perform crisis management tasks. These include activities consisting of preventing crisis situations, preparing to take control over them by means of planned actions, responding in the event of crisis situations, remedying their effects and restoring critical resources and infrastructure (Article 2, Crisis Management Act of 26 April 2007, Journal of Laws of 2020, item 1856). The implementation of tasks in the field of crisis management in the Polish legal system is based on the principle of single-handed management in order to be able to take appropriate preventive or follow-up actions faster and more effectively (Radwanowicz-Wanczewska \& Prokop, 2009: 784-785). At the municipality level, the competent authority for crisis management issues is its executive body (village mayor, town mayor, city president), which performs the management, planning and organisational functions in this respect (Czuryk, 2017: 51). In the poviat area, the authority competent in matters of crisis management is the starost as the head of the poviat management board. In the case of the highest-level unit of the state's territorial divisions (voivodeship) and at the central level, the crisis management tasks are within the responsibility of the central government administration bodies, namely the voivodeship governor (wojewoda) and the Council of Ministers respectively (Kostrubiec, 2018: 37-38).

The tasks of local government include undertaking specific actions in the situation of where a state of natural disaster is announced. They are aimed at preventing the effects of a natural disaster or remedying them. Powers in this respect was granted to one-person local government bodies (Karpiuk, 2014b: 59). If the state of a natural disaster was introduced only in the area of one municipality, the tasks in the analysed scope are performed by the executive body of the municipality. In the case of a poviat, the relevant responsibilities are conferred on the starost if the state of a natural disaster has been imposed on the area of more than one municipality belonging to the poviat (Article 8 items 1-2, Act of 18 April 2002 on the state of a natural disaster, Journal of Laws of 2017, item 1897). At the voivodeship (regional) level, the relevant powers are not vested in the regional self-government bodies, as they are granted to the voivodeship governor as an administration body of the central government (Kostrubiec, 2018: 38).

During the state of emergency, the public authorities, including local government, operate within the existing organisational structures of the state and within the scope of their powers (Article 8, Act of 21 June 2002 on the state of emergency, Journal of Laws of 2017, item 1928). However, if the municipal, poviat or voivodeship self-government bodies do not demonstrate sufficient effectiveness in performing public tasks or in carrying out activities resulting from the provisions on the introduction of a state of emergency, the President of the Council of Ministers, at the request of the competent voivodeship governor, may 
J. Kostrubiec: The Role of Public Order Regulations as Acts of Local Law in the Performance of Tasks in the Field of Public Security by Local Self-government in Poland

suspend the local government bodies and appoint a compulsory administrator in their place (Czuryk \& Kostrubiec, 2019: 34-35).

Regardless of the sphere of public security, the local government in Poland has been equipped with broad powers in the area of military security. The tasks of the local government in this area are related in particular to the introduction of martial law (Orzeszyna, 2013: 170) and carrying out activities related to the implementation of the universal military duty and cooperation with military authorities in the area of administration of personnel reserves (Kostrubiec, 2017: 106).

\subsection{Acts of local law of bodies of local government}

\subsubsection{Acts of local law adopted by bodies of local government in Poland}

The system of sources of law in Poland was based on the positive law concept and is a "closed" system (Kostrubiec, 2013: 42; Judgment of the Constitutional Tribunal of 28 June 2000, K. 25/99, OTK ZU 2000, No 5, item 141). It is characterised by "duality", which consists in adopting the division of sources of law into universally and internally applicable (Article 87 and 93, Constitution of the Republic of Poland of 1997). The origins of this division are related to the German 19th-century doctrine of law (Mojak, 2009: 43). Generally applicable law has unlimited scope of applicability in the subjective sense. Acts of local law are sources of generally applicable law, but they apply only in the area of responsibility of the bodies which adopted them (Article 87(2) of the Constitution of the Republic of Poland of 1997). Both local government bodies and local bodies of the central government have been equipped with the power to enact local law in Poland on the basis of and as authorised by the statutory law (Article 94, Constitution of the Republic of Poland of 1997).

Acts of local law have a special place in the system of generally applicable sources of law for several reasons. First, the entities adopting acts of local law, which cover public administration bodies, including local authorities, but not bodies of legislative power, have a special status. This means that the legislative powers of local government are not only an expression of administrative decentralisation, but are also a manifestation of political decentralisation (Dąbek, 2007: 49-50). Therefore, the classical function of executive power, including public administration, referred to in Montesquieu's doctrine as the "power to interfere" today becomes difficult to maintain (Kostrubiec, 2012: 123). It should be stressed, however, that acts of local law must not exceed the provisions laid down by law (Sikora, 2017: 61). The uniqueness of local legislation also lies in its limited territorial scope. The area of application of a local law act shall be determined by the territorial jurisdiction of the law-making body. Thus, a local government unit 
can adapt the content of the law being adopted to the local conditions and is given the opportunity for quick legislative intervention. Therefore, acts of local law, in particular public order regulations, are of particular importance in situations related to the threat to the life or health of the local population (Karpiuk \& Kostrubiec, 2017: 90-91).

Normative acts adopted by the local government in Poland are of a different nature in terms of content and legal force. Not every normative act issued by a local government body will be an act of local law (Kostrubiec, 2011: 337). The classification of a particular act adopted by local government as an act of local law will be determined by the inclusion in its content of general and abstract rules and the adoption of the act on the basis of the statutory authorisation and within its limits. In the Polish legal system, it is not permissible to independently adopt sub-statutory acts, namely those adopted without the authorisation laid down in the statutory law (Wiącek, 2013: 105). It is also important to stress the obligation to publish acts of local law in the regional official gazette. All acts of local law have the same legal force and occupy the same place in the hierarchy of sources of law, regardless of whether they are adopted by local government bodies or local bodies of the central government (Lipski, 2009: 27). The legal force of a local law act is also not affected by the fact that it was issued by a municipal, poviat or regional authority.

The following bodies of local government units in Poland have the power to enact local law in Poland: the municipal council and, exceptionally and only to a certain extent (public order regulations) the executive bodies of municipality (village mayor, town mayor, city president); the poviat council and exceptionally and only to a certain extent (public order regulations) the poviat executive body (poviat management board) and the regional (voivodeship) assembly. Local authorities are prohibited to sub-delegate their law-making powers, as confirmed by relevant case-law (Judgment of the Supreme Administrative Court of 10 January 1995, SA/Kr 2564/94, ONSA 1996 No 1, item 28). This means that local authorities cannot transfer to their executive bodies the power to adopt acts of local law. Acts of local law issued by local government bodies are subject to the review of the voivodeship governor, i.e. the local body of central government authority, in terms of their compliance with the acts of generally applicable law.

Acts of local law are subject to different classifications by Polish scholars in the field (Sikora, 2017: 80-101). Due to the status of the body entitled to adopt them, one may distinguish acts of local law adopted by local government bodies and acts of local law adopted by local bodies of the central administration. Based on the criterion of the type of statutory authorisation for their creation, acts of local law adopted under a general statutory authorisation (statutes provisions, public order regulations) and acts of local law adopted on the basis of a specific statutory 
J. Kostrubiec: The Role of Public Order Regulations as Acts of Local Law in the Performance of Tasks in the Field of Public Security by Local Self-government in Poland

authorisation (acts of an implementing nature) are distinguished. In legal literature, acts of local law are most often divided on the basis of the criterion of matter of regulation. Based on that criterion, acts of local law of an executive nature, acts of local law of an organisational and systemic nature and public order regulations shall be distinguished, the latter being the subject of further discussion herein.

\subsubsection{Public order regulations as acts of local law adopted by bodies of local government in Poland}

A particular category of local law is public order regulations. The uniqueness of local public order regulations is manifested in several spheres. Firstly, they are acts which are of an independent nature. They can be adopted on the basis of the general authorisation contained in the law governing the system of the local government unit concerned (Dąbek, 2016: 154). Secondly, public order regulations are a manifestation of the activities of the local government in the field of public security/safety, which consists in the ad hoc and rapid prevention of negative situations of an emergency, random or exceptional nature, such as a natural disaster, a catastrophe or an epidemic (Kotulski, 2001: 37). Thirdly, the Polish legislature granted the right to enact public order regulations only at the level of municipal and poviat government, with the exception of regional government, as this power is conferred at this level on the voivodeship governor who is a body of central government (Kostrubiec, 2018: 37). Fourthly, the uniqueness of public order regulations is linked to the specific purpose of their regulation, which is to fill a kind of gap in the legal system. Public order regulations should include "new" norms. It is a question of regulating that sphere of social relations which the legislature did not cover or could not have covered because of the existence of extraordinary circumstances threatening the local community (Dąbek, 2007: 128). Fifthly, public authorities, when adopting public order regulations, have greater freedom to shape their content compared to other types of acts of local law. The limits of these public order regulations are set by the purpose of regulation, which may be to protect the life or health of citizens, property, the environment and to ensure order, peace and public security. Sixthly, public order regulations may provide for a penalty for their infringement in the form of a fine imposed in accordance with the rules laid down in the law on petty offences.

In conclusion, it must be stated that the possibility of enacting local law is conditional on the cumulative fulfilment of the three conditions: objective, subjective and territorial (Dąbek, 2007: 129; Sikora, 2017: 100). The objective condition concerns the legal status. Public law regulations may be adopted only to the extent not yet regulated by generally applicable legislation. The objective condition is met where there is a kind of gap in the law. It is to eliminate the 
possibility of duplicating or modifying legal rules applicable to the facts concerned. The subjective condition relates to the facts. It is met if, in the opinion of the local government body issuing the public order regulations, the legally protected goods such as life, health or property, have been or may be affected. The territorial condition consists in the occurrence of a threat in the area in which the issuing body operates.

\subsubsection{Status of local law acts adopted by local government bodies in the Visegrad Group countries}

The model of local government law-making applied in Poland is typical of the Visegrad Group countries, regardless of the fact that in each of them specific solutions were also adopted (Fábián, 2020: 970-971).

In the light of Article 68 and Article 71(2) of the Constitution of the Slovak Republic, local government may adopt normative acts having the status of generally applicable sources of law, both in the performance of local government's own tasks and in the field of delegated tasks of central government administration. It is interesting that local government bodies in Slovakia can enact provisions with the force of generally applicable law even without specific statutory authorisation. In such a case, however, local authorities may not use their law-making powers to impose certain obligations on citizens. In this case, the relevant authorisation by statutory law is required (Mihálik \& Šramel, 2019: 397-398).

In the Czech Republic, the powers of local self-government in the regulation of local law as generally applicable sources of law are very generally defined in the Czech Constitution. In accordance with Article 104(3) of the Czech Constitution, "Representative bodies may, within the limits of their jurisdiction, issue generally binding ordinances" (The Constitution of the Czech Republic, No. 1/1993 Coll., adopted on 16 December 1992, available at: https://www.psp.cz/ en/docs/laws/constitution.html, March 10, 2020). Therefore, detailed regulation in this field had to be included in the law on local government. In the light of the Act on Municipalities of 2000, there are four main areas in which acts of local law may be adopted (Article 10, the Act dated April 12, 2000 on Municipalities (Establishment of Municipalities), 128/2000, Coll., available at: https://www.mvcr.cz, March 10, 2020). A municipality may adopt acts having the force of generally binding sources of law for the purpose of: 1) safeguarding local affairs in public order; especially it may stipulate which particular activities that could disturb the public peace in the municipality or could run counter to the good morals, protection of safety, health and property can be performed solely on sites and at times specifically determined by a binding ordinance, or stipulate that such activities are prohibited in some public premises in the municipality; 2) organizing, holding and terminating publicly accessible sporting and cultural 
J. Kostrubiec: The Role of Public Order Regulations as Acts of Local Law in the Performance of Tasks in the Field of Public Security by Local Self-government in Poland

events, including dances and discotheques, by stipulating binding conditions to an extent necessary to secure public order; 3 ) maintaining the cleanliness of streets and other public spaces, for the protection of the environment, greenery in builtup areas and other public green space, and for using the municipality's amenities serving public needs and 4) when laid down by a special Act. In view of the above, the role of acts of local law adopted by local government bodies in the Czech Republic to ensure public security and order is as important as in Poland. It is also worth noting the importance of acts of local law in the area of local fees and taxes (Radvan, 2020: 13), thus related to the sphere of economic security.

Concerning the status of acts of local law adopted by local authorities in Hungary, it should be pointed out that, following the entry into force of The Fundamental Law of Hungary (The Fundamental Law of Hungary, 25 April 2011, Magyar Közlöny, No 43/2011, available at: https://www.parlament.hu/en/web/house-ofthe-national-assembly, March 10, 2020), the concept of local government itself has also changed. The status of local government previously set out in the constitutional regulation as a fundamental right of the local and regional communities has been replaced in the new constitution by a specific set of powers (Article 31(1) of the Fundamental Law of Hungary). Moreover, pursuant to Article 34(1) of the Hungarian Constitution, local governments and state organs shall cooperate to achieve community goals. The established scholarly opinion of local government law points out that in Hungary, following the entry into force of the Fundamental Law of 2011, there was a kind of change from an "autonomous" model to an "integrated" model (Hoffman, 2018: 933-934). As regards the sources of law, the Fundamental Law of Hungary of 2011 lists, in addition to statutory acts, government decrees, prime ministerial decrees, ministerial decrees, decrees of the Governor of the Hungarian National Bank, decrees of the heads of independent regulatory organs, also local government decrees, which belong to the sources of generally applicable law (Article T (2), The Fundamental Law of Hungary). In the light of Article 32(2) of the Fundamental Law of Hungary, acting within their functions, local governments shall adopt local government decrees to regulate local social relations not regulated by an Act or on the basis of authorisation by an Act. Legal acts taken by local government bodies must not conflict with other applicable provisions. Local governments shall send local government decrees to the capital or county government office immediately after their promulgation (Article 32 (4), The Fundamental Law of Hungary). If the capital or county government office finds the local government decree or any of its provisions to be in breach of any law, it may initiate a judicial review of the local government decree (Hoffman \& Rozsnyai, 2015: 489-490). 


\subsection{Rules of adopting public order regulations by local (municipal) government bodies}

The municipal council enacts public order regulations in the form of a resolution to ensure order, peace and public security (Article 40 (3) of the Act on municipal government). The condition for enacting acts of local law of a public-order nature is the concurrent fulfilment of two conditions. First, it is necessary for the protection of values such as the life or health of citizens, order, peace and public security. Secondly, a municipal body may enact public order regulations only to the extent not regulated in separate statutory laws or other generally applicable regulations. The term "necessary" should be interpreted as absolutely necessary, indispensable (Judgment of the Voivodeship (Regional) Administrative Court in Poznań of December 8, 2010, IV SA / Po 793/10, LEX No. 821207). On the basis of the jurisprudence of administrative courts, the non-regulated extent occurs when there are no other regulations in the system of generally applicable law that allow for the elimination of phenomena found by the municipality, undesirable in the light of this provision (Judgment of the Supreme Administrative Court of 11 July 2006, II GSK 68/06, LEX No. 267157). Public order regulations are therefore of a subsidiary nature and cannot be used for the day-to-day management of the municipality (Judgment of the Voivodeship (Regional) Administrative Court in Gorzów Wielkopolski of 11 March 2010, II SA / Go 72/10, LEX No. 599180). Conditions related to the issuance of public order regulations by municipal bodies are not subject to an extensive interpretation (Judgment of the Supreme Administrative Court of 13 February 2018, II OSK 994/16, ONSAiWSA 2019, No. 5, item 79). For this reason, except for the cases provided for by the legislature, the municipal council cannot enact public order regulations, even if the lack of such regulation could pose a threat to specific goods (Karpiuk, 2015: 29). Public order regulations may provide for a fine for their violation, which is imposed in the manner and on the terms specified in the law on petty offences (Article 40 (4) of the Act on municipal government). The attaching of sanction to public order regulations is optional and depends on the discretion of the municipal body concerned.

In cases of urgency, in order to ensure a rapid and effective response to a state of emergency of the legally indicated values, public order regulations may be issued by municipal executive bodies in the form of an order. In this case, there must be not two, but three cumulative conditions: 1) the matters under regulation are not governed by generally applicable provisions ("non regulated extent"); 2) the adoption of public order regulations by the executive body of the municipality is necessary to protect the life or health of citizens and to ensure order, peace and public security; 3) there is a case of "urgency" (Article 41(2) of the Act on municipal government). The condition of the case of "urgency" is met when the municipal council is not able to convene a meeting, and due to the threat itself or 
J. Kostrubiec: The Role of Public Order Regulations as Acts of Local Law in the Performance of Tasks in the Field of Public Security by Local Self-government in Poland

its escalation and the spread of the negative effects of this threat, it is necessary to issue immediate public order regulations (Czuryk \& Kostrubiec, 2019: 43). The public order regulations adopted by the municipal executive bodies are not of an independent nature, since they are subject to approval at the next session of the municipal council (Article 41(3) of the Act on municipal government). The municipal council must not approve an order which does not meet the three conditions referred to above. Where the municipal legislative body refuses to approve the order or if the executive body does not present the order for approval by the council, the municipal legislative body shall set a time limit for the expiry of the existing order with the ex nunc effect. As can be seen, the legitimacy of public order regulations issued by the village mayor, town mayor or city president depends not only on the fulfilment of a substantive condition relating to the occurrence of "urgency'", but also on the formal condition relating to the submission of an act of local law for approval by the municipal council. The executive body of the municipality is obliged to send the public order regulations issued by both the council and the executive body, the day after they are adopted, to the attention of the mayors of the neighbouring municipalities and the starost of the poviat in which the municipality is situated (Article 41(5) of the Act on municipal government).

\subsection{Rules of adopting public order regulations by poviat government bodies}

Public order regulations may be adopted after certain conditions have been met by poviat bodies. The Polish legislature has introduced the requirement of cumulative fulfilment of the three conditions (Kotulski, 2011: 35-36). Firstly, the public regulations may be established in particularly justified cases by the poviat council if it is necessary to protect the life, health and property of citizens, to protect the natural environment, and to ensure public order, peace and security (subjective condition) (Article 41 Section 1, Act on poviat government). Secondly, as in the case of the municipality, public order regulations may be adopted by the poviat only to the extent not regulated in separate generally applicable regulations (the objective condition). Thirdly, poviat public order regulations are adopted when the reasons for their issuance occur within the territory of more than one municipality (the territorial condition). Similarly as in the case of a municipality, public order regulations may provide for fines, which are imposed in accordance with the procedure and principles laid down in the law on petty offences (Article 41 (1) to (2) of the Act on poviat government).

In situations of urgency, local law acts on public order may be issued by the poviat board, which is the collective executive body of the poviat (Article 42 (2) of the Act on poviat government). These acts are subject to approval at the next session of the legislative body of the poviat government, i.e. the poviat council. The public 
order regulations issued by the executive body of a poviat cease to be valid if they are not submitted for approval or if the poviat council refuses to approve them. The enactment of public order regulations by the poviat board may take place in exceptional situations, namely when the actual state of affairs justifies the necessity of an immediate response. At the same time the poviat council has no possibility to undertake legal actions within such scope and time which is necessary from the point of view of statutorily protected values such as life, health and property of citizens and protection of natural environment. It should be noted that in urgent situations, only the poviat board has the power to enact public order regulations. Such powers are not vested in the starost, who is the chairman of the collective executive body of the poviat (poviat board). Where public order regulations are enacted, the starost is obliged to send them to the attention of executive bodies of the municipalities located in the area of the poviat and to the starosts of the neighbouring poviats the day after the enactment of the public order regulations (Art. $42(4$,$) of the Act on poviat government).$

\section{$5 \quad$ Conclusions}

The considerations contained herein allowed drawing conclusions that have formed the basis for a positive verification of the main thesis, according to which acts of local law, including public order regulations, are one of crucial manifestations of independence of local government and an expression of the legislative decentralization of state's activity, which is necessary for local government bodies to effectively perform their tasks in the field of security and public order. The validity of the research thesis formulated in the article is confirmed by the following conclusions, which result from the research conducted.

Firstly, the Polish legislature has entrusted local and regional government entities with a number of obligations related to ensuring public safety and order. Secondly, local government identifies threats in its area most quickly and adequately and verifies the needs of its population, which is why it is best prepared to meet these needs. Thirdly, when carrying out a wide range of tasks in the field of ensuring security, local government does not always have at its disposal appropriate legal means under regulations applicable at the given moment. Fourthly, the role of public order regulations as acts of local law belonging to the sources of universally binding law is to fill some gaps in the legal system to protect certain goods, such as life, health or property. Fifthly, the possibility of making new legal norms by means of public order regulations is important in the context of the rule of law and the related principle of the specificity of legal provisions as standards of a democratic state ruled by law (Koksanowicz, 2014: 473). Sixthly, the current threats, which are often characterized by high dynamics and unpredictable consequences, require local government bodies to respond quickly and effectively 
J. Kostrubiec: The Role of Public Order Regulations as Acts of Local Law in the Performance of Tasks in the Field of Public Security by Local Self-government in Poland

in the implementation of tasks related to ensuring public safety and order. Seventhly, public order regulations, which may be enacted to the extent not regulated in separate statutory acts or other generally applicable regulations, are characterized by a relatively wide discretion margin in developing their content compared to other types of local law. For this reason, they are particularly good measures in the implementation of tasks by local government bodies in the field of ensuring public safety and order. Eighthly, the possibility of a quick lawmaking intervention of local government bodies, which largely determines the effective neutralization of potential or actual threats, is closely related to the rules of promulgation characteristic of public order regulations. Public order regulations become effective three days after their promulgation. However, they may enter into force at a shorter date, and even on the day of their promulgation. They are subject to promulgation through public notices, as well as in a manner customary in a given area or in the mass media. To sum up, it should be stated that the conducted analysis and the conclusions drawn allow the assumption that the research thesis proposed can be verified as true, and thus the aim of the article has been achieved.

Regardless of the conclusions for the currently applicable law (de lege lata) presented above, referring to the practical sphere related to the tasks of local government in the sphere of security, it should be emphasized that in the current situation in Poland related to the COVID-19 pandemic, the local government experiences the recentralization of tasks rather than the extension of powers related to the coordination of activities for public security/safety, including epidemiological safety (Karpiuk \& Kostrubiec, 2018: 66; Lipowicz, 2020: 31). In such a situation, it would be worth using the thorough knowledge of local government to a greater extent and considering as a postulate for the law as it should stand (de lege ferenda) using the competence of local government in the area of security, including in the area of adopting public order regulations, to relieve the central government administration and respond more effectively to the threats of the COVID-19 pandemic, where the promptness of response plays a key role.

\section{References:}

Czuryk, M., Karpiuk, M. \& Kostrubiec, J. (eds.) (2015) Samorzad terytorialny w państwach Unii Europejskiej (Warsaw: Wydawnictwo Akademii Obrony Narodowej). Czuryk, M., Dunaj, K., Karpiuk, M. \& Prokop, K. (2016) Prawo zarzadzania kryzysowego. Zarys systemu (Olsztyn: Uniwersytet Warmińsko-Mazurski w Olsztynie).

Czuryk, M. (2017) Zadania i kompetencje samorządu terytorialnego w zakresie zarządzania kryzysowego, In: Karpiuk, M., Mazuryk, M. \& Wieczorek, I. (eds.) Zadania $i$ kompetencje samorzadu terytorialnego $w$ zakresie porzadku publicznego $i$ 
J. Kostrubiec: The Role of Public Order Regulations as Acts of Local Law in the Performance of Tasks in the Field of Public Security by Local Self-government in

Poland

bezpieczeństwa obywateli, obronności oraz ochrony przeciwpożarowej $i$ przeciwpowodziowej (Łódź: Narodowy Instytut Samorządu Terytorialnego), pp. 48-57.

Czuryk, M. \& Kostrubiec, J. (2019) The legal status of local self-government in the field of public security, Studia nad Autorytaryzmem i Totalitaryzmem, 41(1), pp. 33-47, https://doi.org/10.19195/2300-7249.41.1.3.

Dąbek, D. (2007) Prawo miejscowe (Warsaw: Wolters Kluwer).

Dąbek, D. (2016) Tworzenie prawa administracyjnego, In: Jakimowicz, W. (ed.) Przewodnik po prawie administracyjnym (Warsaw: Wolters Kluwer), pp. 101-209.

Dolnicki, B. (ed.) (2018) Źródta prawa w samorządzie terytorialnym (Warsaw: Wolters Kluwer).

Dróżdż, M. (2014) Security of sports events in Poland - Polish Act on Mass Events Security, Ius Novum, 2, pp. 171-185.

Fábián, A. (2020) On the Legal Basis of the Lawmaking by Local Self-Governments - an International Overview, Lex localis - Journal of Local Self-Government, 18(4), pp. 955975, https://doi.org/10.4335/18.3.955-975(2020).

Hoffman, I. \& Rozsnyai, K. (2015) The Supervision of Self-Government Bodies' Regulations in Hungary, Lex localis - Journal of Local Self-Government, 13(3), pp. 485502, https://doi.org/10.4335/13.3.485-502(2015).

Hoffman, I. (2018) Challenges of the Implementation of the European Charter of Local Self-Government in the Hungarian Legislation, Lex localis - Journal of Local SelfGovernment, 16(4), pp. 929-938, https://doi.org/10.4335/16.4.929-938(2018).

Karpiuk, M. (2013) Zadania i kompetencje zespolonej administracji rzadowej $w$ sferze bezpieczeństwa narodowego Rzeczypospolitej Polskiej. Aspekty materialne i formalne (Warsaw: Wydawnictwo Akademii Obrony Narodowej).

Karpiuk, M. (2014a) Miejsce samorządu terytorialnego $w$ przestrzeni bezpieczeństwa narodowego (Warsaw: Wydawnictwo Akademii Obrony Narodowej).

Karpiuk, M. (2014b) Zasady działania samorządu lokalnego w czasie stanu klęski żywiołowej, Annales Universitatis Mariae Curie-Skłodowska, sectio G-Ius, 61(2), pp. 51-60, http://dx.doi.org/10.17951/g.2014.61.2.51.

Karpiuk, M. (2015) Przepisy porządkowe jako szczególny rodzaj prawa miejscowego, Studia Iuridica Lublinensia, 24(4), pp. 21-34, http://dx.doi.org/10.17951/sil.2015.24.4.21.

Karpiuk, M. (2019) Position of the Local Government of Commune Level in the Space of Security and Public Order, Studia Iuridica Lublinensia, 28(2), pp. 27-39, http://dx.doi.org/10.17951/sil.2019.28.2.27-39.

Karpiuk, M. (2020) Bezpieczeństwo imprez masowych (Olsztyn: Uniwersytet WarmińskoMazurski w Olsztynie).

Karpiuk, M., Kostrubiec, J., Paździor, M., Popik-Chorąży, K. \& Sikora, K. (2013) Legislacja administracyjna (Warsaw: Wydawnictwo Difin).

Karpiuk, M. \& Kostrubiec, J. (2017) Rechtsstatus der territorialen Selbstverwaltung in Polen (Olsztyn: Uniwersytet Warmińsko-Mazurski w Olsztynie), available at: https://www.ceeol.com/search/book-detail?id=621502 (March 15, 2020).

Karpiuk, M. \& Kostrubiec, J. (2018) The Voivodeship Governor's Role in Health Safety, $\begin{array}{llll}\text { Studia Iuridica } & \text { Lublinensia, }\end{array}$ http://dx.doi.org/10.17951/sil.2018.27.2.65.

Koksanowicz, G. (2014) Zasada określoności przepisów w procesie stanowienia prawa, $\begin{array}{llll}\text { Studia Iuridica } & \text { Lublinensia, }\end{array}$ http://dx.doi.org/10.17951/sil.2014.22.0.471. 
J. Kostrubiec: The Role of Public Order Regulations as Acts of Local Law in the Performance of Tasks in the Field of Public Security by Local Self-government in Poland

Kostrubiec, J. (2011) Źródła prawa, In: Dubel, L., Kostrubiec, J., Ławnikowicz, G. \& Markwart, Z., Elementy nauki o państwie i polityce (Warsaw: Wolters Kluwer), pp. 326342.

Kostrubiec, J. (2012) Klasyczna teoria podziału władzy w ujęciu Monteskiusza, In: Bożek, M., Karpiuk, M., Kostrubiec, J. \& Walczuk, K., Zasady ustroju politycznego państwa (Poznań: Polskie Wydawnictwo Prawnicze IURIS), pp. 120-124.

Kostrubiec, J. (2013) Podstawy teorii prawa w legislacji administracyjnej, In: Karpiuk, M., Kostrubiec, J., Paździor, M., Popik-Chorąży, K. \& Sikora, K., Legislacja administracyjna (Warsaw: Wydawnictwo Difin, pp. 13-72.

Kostrubiec, J. (2017) Zadania i kompetencje samorządu terytorialnego w zakresie administracji rezerw osobowych dla celów powszechnego obowiązku obrony, In: Karpiuk, M., Mazuryk, M. \& Wieczorek, I. (eds.) Zadania i kompetencje samorzadu terytorialnego $w$ zakresie porządku publicznego i bezpieczeństwa obywateli, obronności oraz ochrony przeciwpożarowej $i$ przeciwpowodziowej (Łódź: Narodowy Instytut Samorządu Terytorialnego), pp. 105-112.

Kostrubiec, J. (2018) Status of a Voivodship Governor as an Authority Responsible for the Matters of Security and Public Order, Barometr Regionalny. Analizy i Prognozy, 16(5), pp. 35-42, available at: http://br.wszia.edu.pl/zeszyty/pdfs/br54a_04kostrubiec.pdf (March 15, 2020).

Kotulski, M. (2001) Akty prawa miejscowego stanowione przez samorząd terytorialny, Samorzad Terytorialny, 11, pp. 28-42.

Lipowicz, I. (2020) Nowa rola samorządu terytorialnego w państwie współczesnym, Samorzad terytorialny, 7-8, pp. 22-35.

Lipski, J. (2009) Akty prawa miejscowego $w$ świetle regulacji prawnych, orzecznictwa $i$ doktryny (Warsaw: Towarzystwo Naukowe Powszechne S.A.).

Mihálik, J. \& Šramel, B. (2019) Constitutional and Legal Foundations for Local SelfGovernment Law-making: Does the Slovak Republic Need More Precise Legal Regulation?, Lex localis - Journal of Local Self-Government, 17(3), pp. 393-415, https://doi.org/10.4335/17.3.393-415(2019).

Mojak, R. (2009) System źródeł prawa w Konstytucji Rzeczypospolitej Polskiej z 2 kwietnia 1997 r., Studia Iuridica Lublinensia, 12, pp. 27-50.

Orzeszyna, K. (2013) Extraordinary Measures in the Constitution of the Republic of Poland, In: Dunaj, K. \& Stepnowska, M. (eds.) Legal Security (Warsaw: Elipsa), pp. 168186.

Orzeszyna, K., Skwarzyński, M. \& Tabaszewski, R. (2020) Prawo międzynarodowe praw czlowieka (Warsaw: C.H. Beck).

Radwanowicz-Wanczewska, J. \& Prokop, K., Organizacja systemu zarządzania kryzysowego w Polsce, In: Parchomiuk, J., Ulijasz, B. \& Kruk, E. (eds.) Dziesięć lat reformy ustrojowej administracji publicznej $w$ Polsce. Ogólnopolska konferencja naukowa, Łańcut, 12-14 czerwca 2008 r. (Warsaw: Wolters Kluwer), pp. 780-792.

Radvan, M. (2020) Czech tax law (Brno: Masaryk University Press), available at: https://science.law.muni.cz/knihy/monografie/Radvan_Czech_Tax_Law.pdf (October 20, 2000).

Sikora, K. (2017) Istota i charakter prawny aktów prawa miejscowego $w$ zakresie ich sadowoadministracyjnej kontroli (Lublin: Wydawnictwo Uniwersytetu Marii CurieSkłodowskiej).

Skoczylas, J. (2011) Prawo ratownicze (Warsaw: LexisNexis). 
LEX LOCALIS - JOURNAL OF LOCAL SELF-GOVERNMENT

J. Kostrubiec: The Role of Public Order Regulations as Acts of Local Law in the Performance of Tasks in the Field of Public Security by Local Self-government in

Poland

Wiącek, M. (2013) Upoważnienie do wydania samorządowego aktu prawa miejscowego w świetle Konstytucji RP, Zeszyty Naukowe Sądownictwa Administracyjnego, 3(48), pp. 104-114. 